\title{
Post harvest mycobiota of sissoo(Dalbergia sissoo Roxb) grown in north Eastern U.P and their culture filterate potential
}

\author{
Dr.Narendra Kumar \\ Bacteriology and Natural Pesticide Laboratory,Department of Botany,DDU Gorakhpur University, Gorakhpur- \\ 273009 ,
}

\begin{abstract}
Seed samples were collected from 25 places of north eastern U.P from luxuriantly growing and healthy D.sissoo Roxb plants and stored at room temperature for 3 months in presterilized polyethylene bags.Mycofloral analysis showed presence of 15 fungal species which showed variation at district level on the basis of occurence.Mycofloral analysis through blotter method revealed the presence of 15 fungal species and agar plate method 12 fungal species.Seven fungal species of three genera were detected from surface sterilized seeds using blotter method.Twelb fungal species(belonging to 6 genera) and 5 fungal species (of two genera) were detected from unsterilized and sterilized seeds from agar plate method of analysis. The metabolites of most of the fungi showed effect on germination and put A.niger as highly potent.The other fungi in order of potentials for inhibiting seed germination were

F.solani,F.oxysporum,A.tamarri,A.terreus,F.moniliforme,A.phoenicis,A.flavus,Alternaria alternata,Aspergillus candidus,Penicillium glabrum,Rhizopus nigicans and Trichothecium roseum.The metabolite of A.sydowi and Trichoderma viride showed promotive effect on the germination of the seeds of sissoo.A.niger and F.solani caused high degree of inhibition in germination and also caused high degree of mortality.

Key Words; seed mycoflora,shisham,culture filterate,mortality
\end{abstract}

\section{Introduction}

Sissoo or Shisham(Dalbergia sissoo Roxb), a deciduous tree of family Papillionaceae, is an important plant of great economic value .Its wood is very hard and best suitable for furniture.Forest productivity and nursery efficiency depends to a great extant on the quality of the seeds used.One of the easiest and inexpensive method of increasing forest productivity is to use disease free seeds.Unfortunately Shisham is susceptible to dieback, wilt and several other soil borne pathogens(Sah et al.,2003).Richardson(1990)reported several species of Aspergillus,Penicillium,Rhizopus,Alternaria,Fusarium,Chaetomium,Drechslera and Curvularia from forest tree seeds.Mustafa et al(2004) isolated Rhizoctonia solani,Fusarium solani,F.oxusporum,F.moniliforme,Aspergillus niger,Alternaria alternata and Helminthosporium spp.,as seed borne fungi from seed samples of shisham.

In north eastern U.P this plant is suffering from wilting diseases and more thn 30\%plants have been found wilted.No systematic work has been done on post harvest seed mycoflora and their impact on seed germination and mortality in north eastern U.P.In present investigation seed mycoflora of freshly collected and stored seeds of sissoo were studied. The effect of culture filterates of seed borne fungi on seed germination and mortality were compared.

\section{Seed collection}

\section{Materials and Methods}

Twenty five places were visited for collection of seed samples in five districts of north eastern Uttar Pradesh from different age group of sissoo plants

Collection Place

Basti district-Ganeshpur,Kalwari,Makhauda,Chhawni Bazar,Walterganj

in Santkabir nagar district-Baghnagar,Mehdaul,Matiuli,Alinagar,Gagargarh,

in Siddhartha nagar district-Bansi,Itwa,Chandapar,Chilia,Birdpur

inGorakhpur district-Brhalganj,Golabazar,Kauriram,Kusmi,Pali

in Maharajganj district-Nautanwa,Sanduriya,Khucha,Paniyara,Nichlaul

Seeds were collected during 2008,2009,2010 seeding season from the forests and different plalantations of these places of north eastern UP.For seed collection healthy and vigorous growing trees were selected and age group recorded by consulting with local people.Seed samples were collected separately from different trees and composite samples were made by mixing primary samples.From this composite sample smallest 
sample(working sample) were obtained for seed health studies as recommended by international seed testing association(1966) and seed lots were prepared at district level.All the seeds were stored in closed plastic containers in a cool dry place.

\section{Mycoflora analysis of collected and stored seeds}

The seeds were analysed for their mycoflora using agar plate(Muskett,1948)and standard blotter(De Tempe,1953)techniques.In agar plate technique,100seeds were equidistantly spread out on potato dextrose agar medium in separate petri plates,each containing 5 seeds.In blotter test,the seeds were similarily plated on three layered moistened blotter pads in sterilized petriplates. The assay plates were then incubated at $28 \pm 2{ }^{\circ} \mathrm{C}$ and observed daily upto 7 days for appearance of fungal isolates.Pure cultures of each isolates were maintained on a potato dextrose agar slants and identified.

In orde to detect the internal seed mycoflora,the seeds were first surface sterilized with $0.2 \%$ mercuric chloride for five minutes washed with sterilized distilled water and then subjected to agar plate and standard blotter techniques for isolation of the fungi.Excess water was removed from the seed using folds of sterilized blotters.Drying the seeds in sterilized blotters before plating on agar plates helped to reduce bacterial and actinomycete contamination to a great extant.This enables superficial inoculums to be separated from the one which is deep seated(Neergaard,1977).

Fungal identifications were confirmed on the basis of colony characters and by examining the slide preparation under microscope.Keys and description given by Raper and Thom(1949),Gilman(1967),Raper and Fennell(1965),Booth(1971) and Ellis(1971,76) were followed.

\section{Effect of culture filterate of seed borne fungi on germination and mortality on sissoo}

The fungi isolated from seeds were tested for their pathogenic narutre by studying the effects of culture filterates on seed germination and mortality.Tfungal species were cultured in czapeks solutions for 15 days at 28 $\pm 2{ }^{\circ} \mathrm{C}$ in stationary conditions. The cultures were filtered through whatman no- 1 filter paper and the filterates were used to assay the toxin produced by assessing the percentage inhibition of seed germination and mortality of sissoo.

Freshly harvested surface sterilized $(0.1 \%$ mercuric chloride solution) and washed (sterilized water) seeds were soaked separately for overnight in $100 \mathrm{ml}$ of each culture filterate of corresponding sissoo seed fungi in four replication of 25 seeds each. 25 treated seeds were placed in sterilized petridish containing three layers of moist blotters. The number of seeds germinated after 5 days interval for upto 20 days was observed and the final percentage of germination and mortality was recorded till there was no further germination.The controls were maintained by sowing surface sterilized seeds in sterilized blotters.

\section{Dry seed examination}

\section{Results}

Out of a total 1538 seeds examined from 5 seed lots collected from 25 places(Table 1)and composite samples prepared at district level separately it was found that on an average for every hundred seeds 75.6\% were healthy $24.5 \%$ had fungal infection and $0.9 \%$ seeds were damaged by insects(Table 2 )

\section{Mycofloral analysis}

Mycofloral analysis showed presence of 15 fungal species which showed variation at district level on the basis of occurrence(Table 3).A total of fifteen fungal species belonging to seven genera were recorded from unsterilized seeds using moist blotter method(Table 4).

The most frequent genera were Aspergillus represented by seven species followed by Fusarium(represented by three species).Highest percentage incidence were F.moniliforme and A.flavus(7.4 each)followed by Fusarium oxysporum(6.2) F.solani(5.2) and Penicillium glabrum(4.2).Other species of fungi like Alternaria alternata,Aspergillus candidus,A.phoenicus,A.tamarii,A.terreus,A.sydowi,Rhizopus nigricans,Trichothecium roseum,Trichoderma viride occurred less frequently.

Seven fungal species of three genera were detected from surface sterilized seeds using moist blotter method.The most dominant genera were Aspergillus(represented by three species).Highest percentage incidence was of A.flavus(3.7) followed by A.niger and F.solani(2.4 each).Other forms like Alternaria alternata,Aspergillus sydowi,F.moniliforme and F.oxysporum were infrequent.

Twelb fungal species belonging to six genera were detected from unsterilized seeds plated over PDA medium.The most dominant genera were Aspergillus(represented by five species)followed by Fusarium(three species) and Penicillium glabrum.Highest percentage incidence was of A.flavus(16.9) followed by A.niger(13.1),Penicillium glabrum(10.2)F.oxysporum(6.4) and A.sydowi(5.2).Other fungi like Alternaria alternata,Aspergillus candidus,A.tamarii,F.moniliforme,F.solani,Trichoderma viride,Trichithecium roseum were less common. 
Five fungal species of two genera were isolated from surface sterilized seeds using PDA medium.The fungi recorded to be internally seed borne were A.flavus,A.niger,A.sydowi,F.oxysporum and F.solani(Table 4).

In present investigation it was observed that in agar plate method fast growing fungi suppressed the development of other fungi making their detection difficult.Slow growing forms like Penicillium,Trichothecium and Trichoderma were better isolated in blotter method as compared to agar method.The blotter method seems to be superior to agar plate method.

The metabolites of most of the test fungi showed inhibitory effects on germination. The rating of fungi on the basis of inhibitory effects on germination put A.niger as highly potent.The other fungi in order of potentials for inhibiting geed germination F.solani,A,tamari,F.moniliforme,A.phoenicus,A.flavus,F.oxysporum,Alternaria alternata,Aspergillus candidus,Penicillium glabrum,Rhizopus nigricans,Trichothecium roseum. The metabolite of A.sydowi and Trichoderma viride showed promotive effect on the germination of seeds of D.sissoo as compared to control.It is evident from table 5, that A.niger and F.solani caused high degree of mortality and reduction in germination.

\section{Discussion}

Several other fungal species were isolated by different workers from shisham seeds viz.,Aspergillus,Penicillium,Rhizopus,Alternaria,Fusarium,Chaetomium,Drechslera and Curvularia(Richardson,1990);F.solani and F.pallidoroseum(Ahmad and Bhutta,1993);Alternaria,Aspergillus and Fusarium(Manadhar et al.,2000);A.niger,A.flavus,A.terreus,Alternaria alternate,Chaetomiumsp,Drechslera australiensis,Fusarium pallidoroseum,F.solani,Fusarium sp.,Penicillium spp.,Rhizopus and Geotrichum sp.,(Khan et al.,2001);Rhizoctonia solani,Fusarium solani,F.oxysporum,F.moniliforme,Aspergillus niger,Alternaria alternata and Helminthosporium oryzae(Mustafa et al.,2004) and Fusarium solani,F.moniliforme,F.equiseti,F.oxysporum, F.semitectum, Rhizoctonia solani,Alternaria alternate, Curvularia lunata,Aspergillus niger and Penicillium sp(Rajput et al.,2010)but in present investigation 15 fungal species viz., Alternaria Alternata,Aspergillus candidus,A,flavus,A.niger,A.phoenicis,A.tamarii,A.terreus,A.sydowi,Fusarium

moniliforme,F.oxysporum,F.solani,P.glabrum,Rhizopus nigricans,Trichoderma viride,Trichothecium roseum were isolated.The variation in fungal species may be due to different climatic conditions, isolation periods and different storage containers.

Pre treatment of seeds with chlorine is advocated in seed health testing and many times its use becomes inevitable when saprophytes interfere in the test.Pretreatment however reduce the percentage count of certain seed borne fungal pathogens(De Tempe,1962;Hewett,1964;Limnard,1968;Ram nath et al.,1973;Lo,1973)which in turn is an indication that these fungi are superficially located on the seed surface.During present seed mycofloral studies,blotter test and agar plate method,two incubation methods not complementary to each other were used.In both the techniques sterilized as well as unsterilized seeds were used.The seeds treated with $0.1 \% \mathrm{HgCl} 2$ solution resulted in the lower counts in present investigation.

Rajak et al(1992) studied post harvest mycoflora of some forest trees of Madhya Pradesh and found blotter method to be the best as it yielded maximum number of fungi in comparison to agar plate method.Similarily in present investigation blotter method yielded 15 fungi and agar plate method yielded 12 fungi.

The review of literature reveals that seed germination has been affected by fungal infections and caused mortality in shisham.Vigayan and Rehill(1990) and Pathan et al(2007) reported that Aspergillus flavus,A.niger,F.oxysporum has inhibitory effect on seed germination of shisham seeds.Rajput et al (2010) recorded 50\%germination and $93.3 \%$ mortality when infested with F.solani.In present investigation A.niger,F.solani caused significant reduction in germination and mortality of shisham seeds.

\section{Acknowledgement}

Author is thankful to Head, Department of Botany for providing Laboratory facilities.

\section{References}

[1]. Ahmad,I and Bhutta,A,R(1993)Fungi associated with land scape tree seed in Islamabad,Pakistan.Pakistan J.Phytopathol.,5;126-129.

[2]. Booth,C(1971)The genus Fusarium.Commonwealth Mycological Institute,Kew,Surrey,England ,237pp.

[3]. De Tempe(1962)Comparison of methods of seed health testing.Proc.Int.Seed Test Assoc.,27;819-828.

[4]. De Tempe,J(1953)The blotter method of seed health testing.Proc,Int.Seed test Assocn.,28;133-151.

[5]. Ellis,M.B(1971)Dematiaceous hyphomycetes.Commonwealth Mycological Institue,Kew,Surrey,England,608pp.

[6]. Ellis,M.B(1971)More Dematiaceous hyphomycetes.Commonwealth Mycological Institue,Kew,Surrey,England,507pp.

[7]. Gillman J.C(1967) A manual of soil fungi.Oxford and JBH publishing co. Calcutta.India.

[8]. Hewett,P.D(1964)Testing carrot seeds infected with A.borri sp dauci.Proc.Int,Seed Test Assoc,29;463-471.

[9]. International Seed Testing Association(1985)International rules for seed testing. Seed Science and Technol, 31;299-366.

[10]. Khan,S.M.,Shakir,A.S,Tabssum,M.A and Rehman,A(2001)Isolation and identification of different fungi from disesed shisham tree.Proc of 3rdNat.Conf.of Plant Pathol,Oct 1-3,NARC,Islamabad,pp.44-46. 
[11]. Limnord,T(1968)Ecological aspects of seed health testing.Proc.Int.Seed Test,Assoc.,33;343-513.

[12]. Lo,S.L(1973)Effect of sodium hypochlorite treatment on seed borne organisms and seed germination of the imported vegetable seeds.Pl.Prot.Bull.,15;147-152.

[13]. Manadhar,G. Shresta,S.K,Appanah,S,Allard,G and Amatya,S.M(2000)Fungi associated with dieback of sissoo.Proc.,of Intl,Seminar,Nepal,18;27-29.

[14]. Muskett,A,E(1948)Technique for the examination of seed for the presence of seed borne fungi.Trans.Br.Mycol.Soc.,30;74-83.

[15]. Mustafa,A.,Khan S.M and Rehman ,A(2004)Fungi associated with shisham(Dalbergia sissoo Roxb.) and their control.Pak,J.Phytopathol,16;73-75.

[16]. Neergaard P(1977)Seed pathology vol1and2.Mavmillan press London.

[17]. Pathan,M.A,Rajput,N.A,Jiskani,M.M and Wagan K.H(2007)Studies on intensity of shisham dieback in Sindh and impact of seed borne fungi on seed germination.Pak.J.Agric.Agril Eng., Vet.Sci .23;12-17.

[18]. Rajak, C.K.,Rachana,A,Pandey,A,K(1992)Post harvest mycoflora and its impact on seed quality of some forest trees of Madhya Pradesh.J.Indian bot Soc.,71;107-108.

[19]. Rajput,N.A.,Pathan,M.A,Rajput,A.Q,Jiskani,M.M,Lodhi,A.M,Rajput,S.A and Khaskhali,M.I(2010)Isolation of fungi associated with shisham trees and their effect on seed germination and seedling mortality.Pak.J.Bot.,42(1);369-374.

[20]. Ramnath,Neergaard,P and Mathur,S.B(1970)Identification of Fusarium species on seeds as they occur in blotter test.Proc.Int.Seed Test. Assoc.,35;121-144.

[21]. Raper,K.B and Fennell,D.I(1965)The genus Aspergillus.The Williams and Wilkins Company,Baltimore.686pp.

[22]. Raper,K.B and Thom,C(1949)A Manual of the Penicillia. Boulliere, Tindall and Cox.London,875pp.

[23]. Richardson,M.J(1990)An noted list of seed borne diseases $4^{\text {th }}$ ed ISTA,Zurich.

[24]. Sah,S.P.,Sharma,C.Kand Sehested,F(2003)Possible role of the soil in the sissoo forest decline in Nepal Terai.Plant Soil Environ,49;378-385.

[25]. Vigayan,A.K and Rehill,P.S(1990)Effect of culture filterates of some seed borne fungi of Dalbergia sissoo Roxb.,on seed germination and seedling growth.Indian Forester,116;559-563.

Table1.Seed collection place and age group of plants in north eastern UP

\begin{tabular}{|l|l|}
\hline Name of place & Age group of plants \\
\hline Basti District & \\
Ganeshpur & $30-35$ \\
Kalwari & $24-30$ \\
Makhauda & $49-50$ \\
Chhawni Bazar & $30-35$ \\
Walterganj & $44-50$ \\
\hline Santkabirnagar District & \\
Baghnagar & $30-35$ \\
Mehndawl & $38-40$ \\
Matiuli & $30-35$ \\
Alinagar & $39-45$ \\
Gagargarh & $37-40$ \\
\hline Siddharthanagar district & \\
Bansi & $41-45$ \\
Itwa & $40-45$ \\
Chandapur & $43-46$ \\
Chilia & $40-45$ \\
Birdpur & $48-50$ \\
& \\
\hline Gorakhpur district & \\
Barhalganj & $30-35$ \\
Golabazar & $30-34$ \\
Kauriram & $31-34$ \\
Kusmi & $32-35$ \\
Pali & $28-39$ \\
Maharajganj district & $25-30$ \\
Nautanwa & $30-35$ \\
Sanduriya & $35-40$ \\
,Khucha & $30-35$ \\
Paniyara & $25-30$ \\
Nichlaul &
\end{tabular}

Table2. Dry seed examination of Dalbergia sissoo collected from north Eastern U.P

\begin{tabular}{|c|c|c|c|c|c|c|c|}
\hline \multirow{2}{*}{$\begin{array}{l}\text { Name of } \\
\text { collected place }\end{array}$} & \multirow{2}{*}{$\begin{array}{l}\text { Number of } \\
\text { seed } \\
\text { examined }\end{array}$} & \multirow[t]{2}{*}{ Percent healthy seeds } & \multirow[t]{2}{*}{ Percent diseased seeds } & \multicolumn{4}{|c|}{ Percent category of diseased seeds } \\
\hline & & & & A & $\mathrm{B}$ & $\mathrm{C}$ & $\mathrm{D}$ \\
\hline 1.Basti. & 232 & 86.6 & 13.4 & 6.8 & 2.7 & 2.5 & 1.4 \\
\hline 2.Santkabirnagar & 237 & 74.5 & 25.5 & 10.1 & 11.6 & 3.5 & 0.3 \\
\hline 3.Siddharthanagar & 242 & 71.0 & 29.0 & 19.0 & 6.4 & 3.3 & 0.3 \\
\hline 4.Gorakhpur & 362 & 72.2 & 27.8 & 17.8 & 3.3 & 6.4 & 0.3 \\
\hline 5.Maharajgang & 465 & 73.0 & 27.0 & 17.0 & 6.4 & 1.3 & 2.3 \\
\hline \multicolumn{2}{|l|}{ Total $=1538$} & \multicolumn{6}{|l|}{ Average\%75.6 24.5} \\
\hline
\end{tabular}

A-blackish brown seeds B-black seeds

C-greyish black seeds $\quad$ D-insect damaged seeds 
Post harvest mycobiota of sissoo(Dalbergia sissoo Roxb) grown in north Eastern U.P and their

Table3.Per cent occurrence of isolated fungi from collected and stored seeds of sissoo in different district of north eastern U.P(overall average of five places at district level)

\begin{tabular}{|c|c|c|c|c|c|}
\hline \multirow{2}{*}{ Fungal species } & \multicolumn{5}{|c|}{ Average per centage of isolated fungi } \\
\hline & Basti & Santkabirnagar & Siddharthanagar & Gorakhpur & Maharajgang \\
\hline Alternaria alternata & 2.0 & 1.2 & 2.2 & 2.0 & 1.9 \\
\hline Aspergillus candidus & 2.0 & 2.1 & 2.3 & $2.4-$ & 2.3 \\
\hline A.flavus & 7.5 & 3.7 & 8.9 & 3.6 & 7.4 \\
\hline A.niger & 3.6 & 2.4 & 3.1 & 3.8 & 3.4 \\
\hline A.phoenicis & 1.4 & 1.2 & 1.0 & 0.9 & 1.3 \\
\hline A.tamarii & 1.0 & 1.2 & 1.2 & 1.4 & 1.0 \\
\hline A.terreus & 1.2 & 1.2 & 1.0 & 1.0 & 1.1 \\
\hline A.sydowi & 2.3 & 2.0 & 2.2 & 1.1 & 2.0 \\
\hline Fusarium moniliforme & 7.3 & 6.9 & 6.0 & 6.4 & 6.3 \\
\hline F.oxysporum & 6.1 & 5.9 & 6.4 & 5.9 & 5.8 \\
\hline F.solani & 5.0 & 4.8 & 4.2 & 3.9 & 4.6 \\
\hline P.glabrum & 4.1 & 4.1 & 4.2 & 4.0 & 4.0 \\
\hline Rhizopus nigricans & 2.1 & 2.3 & 2.2 & 2.4 & 2.0 \\
\hline Trichoderma viride & 2.0 & 2.0 & 2.3 & 1.9 & 1.8 \\
\hline Trichothecium roseum & 1.0 & 1.1 & 1.1 & 1.0 & 1.0 \\
\hline
\end{tabular}

Table 4.Occurrence of different fungi on the seeds of Dalbergia sissoo

\begin{tabular}{|l|l|l|l|l|}
\hline \multirow{2}{*}{ Fungi recorded } & \multicolumn{2}{|l|}{ Moist blotter method } & \multicolumn{2}{l|}{ Potato dextrose agar test } \\
\cline { 2 - 5 } & US & SS & US & SS \\
\hline Alternaria alternata & 2.4 & 1.2 & 3.2 & - \\
\hline Aspergillus candidus & 2.1 & - & 3.3 & - \\
\hline A.flavus & 7.4 & 3.7 & 16.9 & 6.7 \\
\hline A.niger & 3.7 & 2.4 & 13.1 & 3.6 \\
\hline A.phoenicis & 1.2 & - & - & - \\
\hline A.tamarii & 1.3 & - & 3.2 & - \\
\hline A.terreus & 1.3 & - & - & - \\
\hline A.sydowi & 2.4 & 1.0 & 5.2 & 1.1 \\
\hline Fusarium moniliforme & 7.4 & 1.2 & 3.0 & - \\
\hline F.oxysporum & 6.2 & 1.4 & 6.4 & 3.2 \\
\hline F.solani & 5.2 & 2.4 & 3.2 & 3.2 \\
\hline P.glabrum & 4.2 & - & 10.2 & - \\
\hline Rhizopus nigricans & 2.3 & - & - & - \\
\hline Trichoderma viride & 2.1 & - & 1.3 & - \\
\hline Trichothecium roseum & 1.2 & - & 3.1 & - \\
\hline
\end{tabular}

Table 5. Effect of culture filterate of fungi on seed germination and seedling mortality of sissoo

\begin{tabular}{|l|l|l|}
\hline Fungal species & Percent germination & Percent mortality \\
\hline Alternaria alternata & 65.5 & 34.5 \\
\hline Aspergillus candidus & 65.6 & 34.4 \\
\hline A.flavus & 61.4 & 38.6 \\
\hline A.niger & 6.0 & 94.0 \\
\hline A.phoenicis & 58.6 & 41.4 \\
\hline A.tamarii & 40.2 & 59.8 \\
\hline A.terreus & 40.6 & 59.4 \\
\hline A.sydowi & 89.4 & 10.6 \\
\hline Fusarium moniliforme & 49.5 & 50.5 \\
\hline F.oxysporum & 35.4 & 64.6 \\
\hline F.solani & 24.2 & 75.8 \\
\hline P.glabrum & 65.9 & 34.1 \\
\hline Rhizopus nigricans & 66.4 & 33.6 \\
\hline Trichoderma viride & 85.3 & 14.7 \\
\hline Trichothecium roseum & 67.4 & 32.6 \\
\hline Sterilized distilled water(control) & 84.3 & 15.7 \\
\hline & &
\end{tabular}

